\title{
PERENCANAAN PEMELIHARAAN MESIN PRODUKSI DENGAN MENGGUNAKAN METODE RELIABILITY CENTERED MAINTENANCE (RCM) (Studi Kasus: PT. S)
}

\author{
Dwi Prasetya ${ }^{1}$, Ika Widya Ardhyani ${ }^{2}$ \\ e-mail : dwiprasetya27@gmail.com, ika.widya.ardhyani@gmail.com \\ Fakultas Teknik, Jurusan Teknik Industri, Universitas Maarif Hasyim Latif \\ Jl. Ngelom Megare, Taman Sidoarjo 61257
}

\begin{abstract}
PT. S is a company that produces steel pipe. As a manufacturing company, the company relies heavily on its production machines, one of the main engines in this company is mill 303. However, the high frequency of failure and downtime caused the production decreased. This research use reliability centered maintenance (RCM) method. This method is used to determine the machine maintenance schedule as well and the interval optimal time. The stages of this research begin with determining the critical machine then make the system description followed by FMEA analysis, ABC analysis to determine critical component, FTA analysis, analysis of time distribution up to interval optimum maintenance. The result of this research is known 11 critical component with highest RPN value. 11 components that have been identified then analyzed the distribution of the time to failure and distribution of the time to repair and get the value of MTTR and MTTF. Bearing drive roll is the component with the highest RPN value of 512, the MTTR value of 3.56259, the MTTF value of 730,537 and the optimal maintenance interval of 504.64 hours.
\end{abstract}

Keyword: FMEA, Mill 303, MTTF, MTTR, Optimal maintenance interval, RCM.

\section{PENDAHULUAN}

PT. S merupakan perusahaan yang memproduksi pipa baja. Produk yang dihasilkan oleh PT. S adalah pipa baja lapis seng (Galvanized Pipe) dan pipa hitam (Black Pipe) yang sesuai dengan standar nasional, standar internasional, maupun standar dari PT. S. Adapun standar nasional dan internasional yang diacu di PT. S antara lain : ASTM A53 (Steel pipe for general applications), BS EN 10255 (Steel tube sutable for welding), SNI 0039 (Galvanized steel pipe for waterline), ASTM A252 (Steel pipe for constructural).

PT. S beroperasi 24 jam penuh setiap harinya. Mesin-mesin produksi di perusahaan ini antara lain mill, slitter, end-facing, galvanizing, threading, $S T R$, hydrotest, dan mesin penunjang produksi yang lain. Proses produksi pipa baja sangat tergantung kepada mesin-mesin tersebut, namun tingginya frekuensi kerusakan mesin dan downtime membuat hasil produksi menurun.

Mill 303 memiliki jumlah frekuensi terbesar dengan jumlah 1511 kali. Mesin tersebut memiliki jumlah frekuensi kerusakan kumulatif sebesar $20,7 \%$. Jumlah ini signifikan mengurangi jumlah hasil produksi perusahaan karena menyebabkan mesin berhenti saat proses perbaikan. Disisi lain mesin tersebut merupakan mesin utama pada proses produksi pipa baja di PT. S. Data frekuensi kerusakan mesin dan downtime dapat dilihat pada diagram pareto dibawah ini:

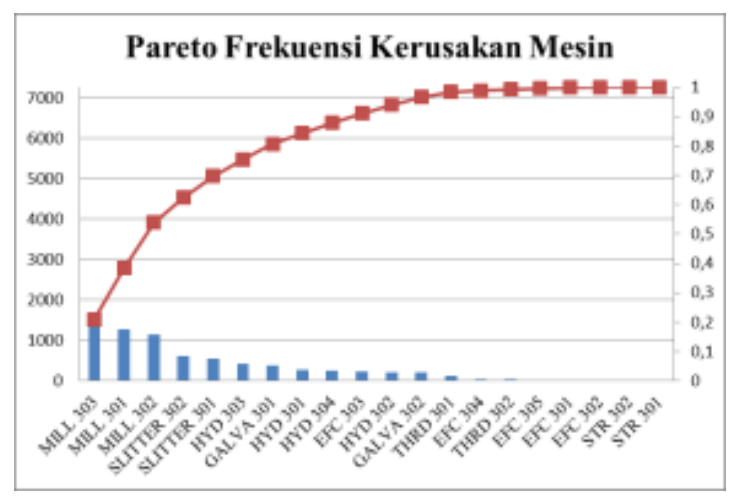

Gambar 1. Diagram pareto frekuensi kerusakan mesin

Berdasarkan permasalahan diatas, penelitian ini mengusulkan manajemen perawatan mesin dengan metode Reliability Centered Maintenance (RCM). Metode RCM diharapkan dapat mengoptimalkan perawatan pada mesin kritis di lintasan produksi PT. S berdasarkan kerusakan yang ada.

\section{METODE PENELITIAN}

Obyek yang diteliti adalah mesin produksi pipa baja yang mengalami kerusakan di PT. S. Alasan pemilihan obyek ini adalah masih tingginya downtime mesin produksi pipa baja sehingga 
menyebabkan kurang optimalnya hasil produksi dan menimbulkan kerugian bagi perusahaan.

Bab ini akan menjelaskan langkah-langkah yang dilakukan dalam penelitian. Langkah-langkah tersebut diuraikan pada Gambar 2 dibawah ini:

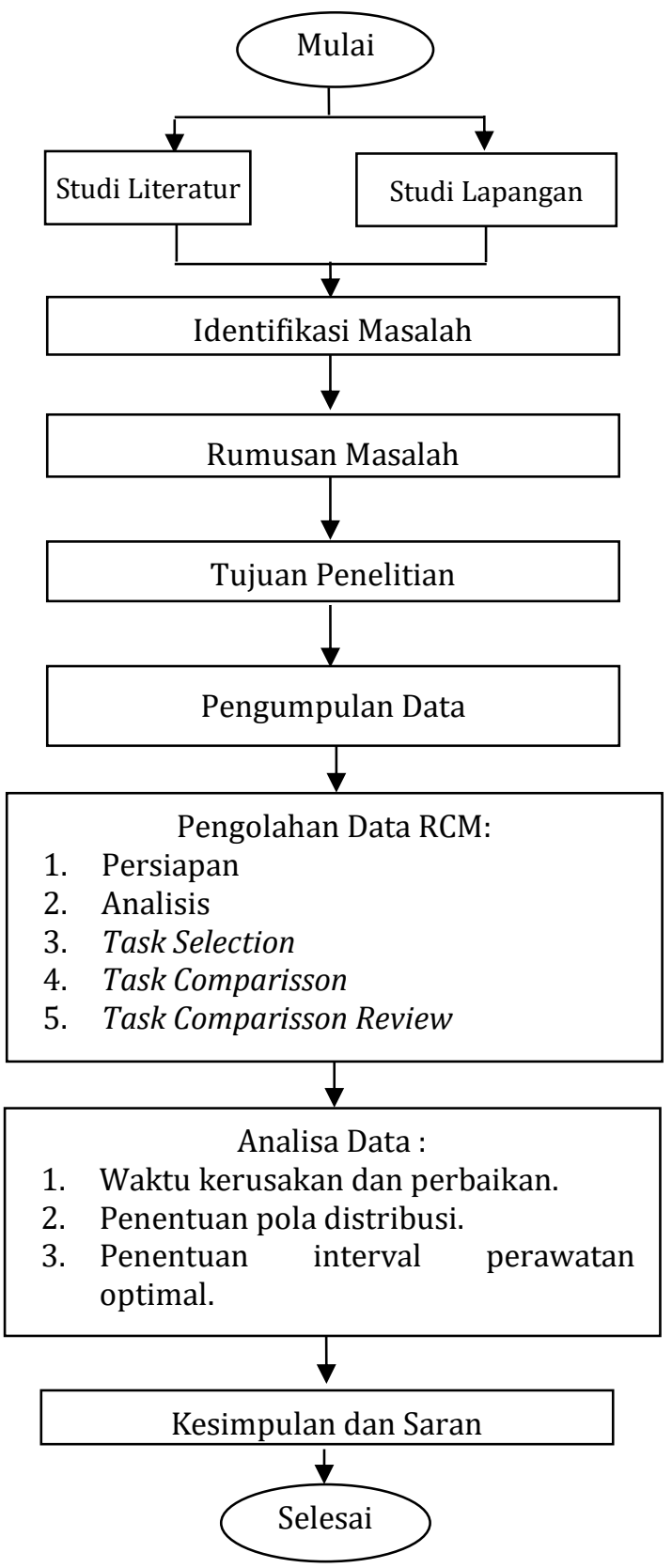

Gambar 2. Flowchart metodologi penelitian

\section{HASIL DAN PEMBAHASAN}

Pengolahan data dan analisis data menggunakan metode reliability centered maintenance, yakni suatu proses yang digunakan untuk menentukan kebutuhan perawatan dari sembarang aset fisik dalam konteks operasinya (Pranata, 2015). Pengolahan data dan analisis data sebagai berikut:

\section{Pemilihan Mesin Kritis}

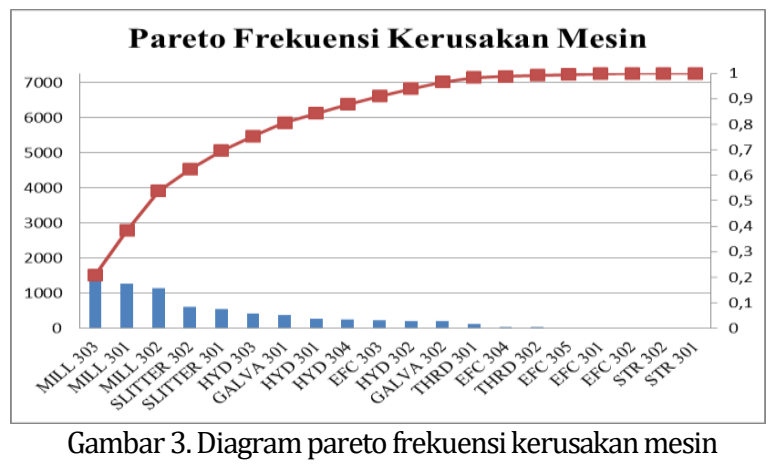

Berdasarkan diagram pareto diatas ditunjukkan bahwa jumlah frekuensi kerusakan terbanyak adalah mesin mill 303. Jumlah frekuensi kerusakan mesin mill 303 dari tahun 2015-2017 sebanyak 1511, total downtime untuk mill 303 sebesar 186.587 menit. Mesin ini memiliki jumlah presentase komulatif sebesar 20,7\% dari total keseluruhan jumlah frekuensi kerusakan mesin yang terjadi. Berdasarkan uraian diatas mesin ini dipilih sebagai obyek penelitian karena jumlah ini signifikan mengurangi jumlah hasil produksi perusahaan karena menyebabkan mesin berhenti saat proses perbaikan. Disisi lain mesin mill 303 tersebut merupakan mesin utama pada proses produksi pipa baja.

\section{Deskripsi Sistem dan Functional Block Diagram}

1. Deskripsi sistem

Deskripsi sitem digunakan unruk mengidentifikasi komponen-komponen yang ada dalam desain sistem dan bagaimana komponen-komponen tersebut dapat beroperasi (Aziz \& Suprawhardana, 2010). Proses utama dalam pembuatan pipa ERW/HFW dimana Slit Coil atau Strip Coil dibentuk secara bertahap melalui sejumlah rangkaian roll dengan metode cold forming hingga berbentuk silindris kemudian dilakukan pengelasan secara otomatis dengan prinsip Electrical Induction pada frekuensi tinggi. Saat pengelasan, terdapat dua perlakuan terhadap pipa yaitu heating dan pressing. Panas dihasilkan oleh induksi arus listrik berfrekuensi tinggi. Bagian-bagian penting dari proses mill : strip joint, accumulator, forming, welding, sizing, cutt-off \& run out. 
2. Functional block diagram

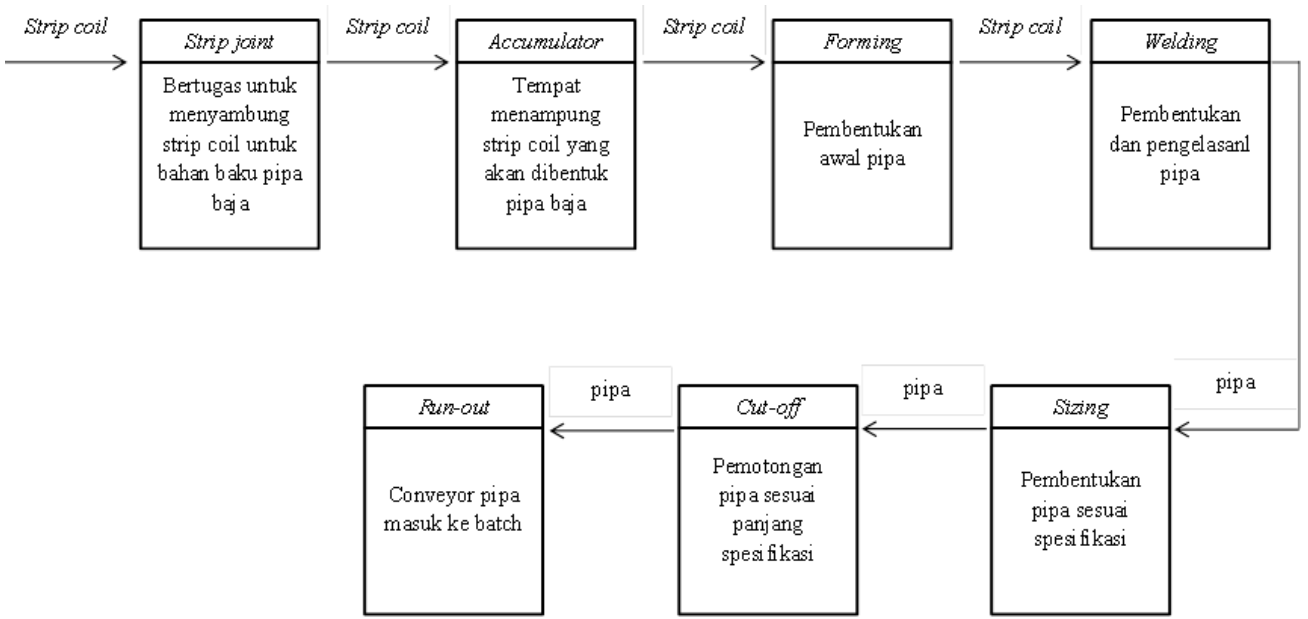

Gambar 4. Functional block diagram

Mesin mill 303 ini memiliki beberapa sub mesin antara lain: strip joint, Accumulator, Forming, Welding, Sizing, Cutt-off \& run out. Sub sistem dalam mesin mill ini saling berkaitan untuk membentuk sebuah proses produksi pipa baja.

\section{Analisis FMEA dan Pemilihan Komponen Kritis}

Failure Mode and Effect Analysis (FMEA) adalah proses mengidentifikasi kegagalan dari suatu komponen yang dapat menyebabkan kegagalan fungsi dari sistem (Aziz \& Suprawhardana, 2010).

Analisis pada tabel failure mode and effect analisys (FMEA) terdiri dari:

1. Function berfungsi untuk mendeskripsikan fungsi komponen yang dianalisis.

2. Functional failure berfungsi untuk menentukan kegagalan yang terjadi pada komponen.

3. Failure modes berfungsi untuk mengidentifikasi penyebab kegagalan yang terjadi pada komponen yang sedang dianalisis.

4. Failure effect berfungsi untuk mengidentifikasi dampak yang ditimbulkan oleh kegagalan fungsi komponen.

5. Saverity digunakan untuk menentukan rating dari dampak yang ditimbulkan oleh kegagalan fungsi komponen yang dianalisis.

6. Occurrence digunakan untuk menentukan rating frekuensi kerusakan komponen yang sedang dianalisis.
7. Detection digunakan untuk menentukan rating kemungkinan sebuah komponen dapat dideteksi terjadi kegagalan fungsi.

8. Risk priority number digunakan untuk menentukan angka prioritas resiko kegagalan fungsi yang didapatkan dari perkalian severity, occurrence, dan detection.

Analiss FMEA menghasilkan nilai RPN komponen mesin mill 303 yang didapatkan dari perkalian saveriy, occurance, dan detection. Hasil perhitungan nilai RPN terbesar adalah komponen bearing drive roll accumulator dengan nilai 512 . Nilai RPN terkecil adalah komponen valbelt run-out dengan nilai 4.

Analisis komponen kritis didasarkan dari rangking jumlah RPN di tabel FMEA. Setelah mendapatkan rangking perhitungan RPN, selanjutnya akan ditentukan prioritas mode kegagalan menggunakan metode $A B C$ untuk dilakukan perbaikan.

Metode $A B C$ mengklasifikasikan persediaan dalam 3 kategori, yaitu: A, B, C Kelompok A mewakili $10-20 \%$ dari total elemen yang mempresentasikan $60-70 \%$ total nilai. Kelompok B mewakili $20 \%$ dari total elemen dan mempresentasikan $20 \%$ total nilai. Dan kelompok C mewakili $60-70 \%$ dari total elemen dan mempresentasikan $10-20 \%$ total nilai. Rekap hasil perhitungan RPN dan analisis ABC dapat dilihat pada Gambar 5 dibawah ini: 


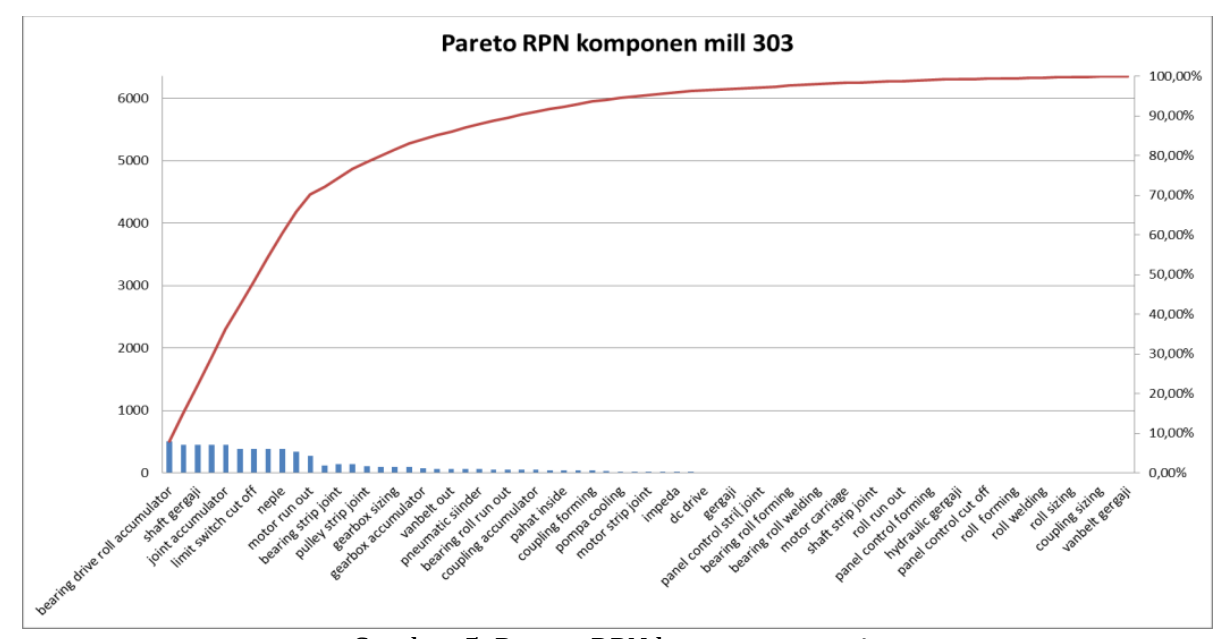

Gambar 5. Pareto RPN komponen mesin

Dari analisis menggunakan metode $\mathrm{ABC}$ didapatkan 11 komponen grade A dengan presentase komulatif sebesar $70,25 \%$ yang dianggap sebagai komponen kritis dari keseluruhan total julah RPN komponen mesin. Komponen-komponen tersebut akan dilakukan analisa lebih mendalam. Adapun 11 komponen kritis antara lain:
1. Bearing Drive Roll Accumulator
2. Selang
3. Shaft Gergaji
4. Bearing Gergaji
5. Joint Accumulator
6. Pulley Gergaji
7. Limit Switch Carriage
8. Fitting

\section{Nepple \\ 10. Solenoid Kick Out \\ 11. Motor Run Out}

\section{Analisis FTA}

Fault tree analysis (FTA) adalah suatu teknik yang digunakan untuk mengidentifikasi resiko yang berperan terhadap terjadinya kegagalan (Hanif et al, 2015).

Analisis FTA pada mesin mill 303 dapat dilihat pada Gambar dibawah ini:

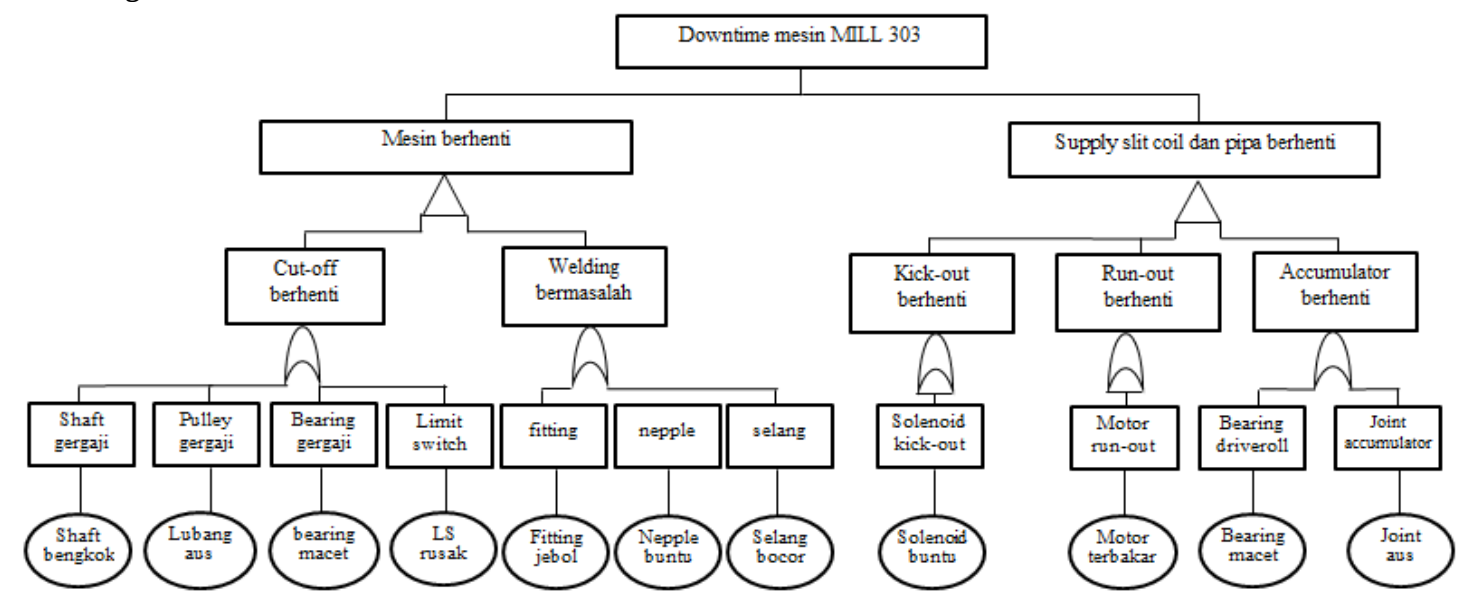

Gambar 6. Fault tree analysis mesin mill 303

Dari analisis FTA diketahui bahwa penyebab utama downtime mesin mill 303 adalah mesin berhenti dan supply slit coil dan pipa berhenti. Mesin berhenti disebabkan oleh cut-off berhenti dan welding bermasalah. Supply slit coil dan pipa berhenti disebabkan oleh kick-out berhenti, run-out berhenti dan accumulator berhenti.
Cut-off berhenti disebabkan oleh shaft gergaji bengkok, pulley gergaji aus, limit swith rusak dan bearing gergaji macet. Welding bermasalah disebabkan oleh fitting jebol, nepple buntu dan selang bocor. Masalah pada welding ini berdampak pada kualitas pengelasan pipa hingga menimbulkan cacat pada pipa. Supply slit coil dan pipa berhenti diebabkan oleh rusaknya kick-out, 
run-out dan accumulator. Kick-out rusak disebabkan oleh solenoid kick-out buntu. Run-out berhenti disebabkan oleh terbakarnya motor runout. Accumulator berhenti disebabkan oleh bearing driveroll macet dan joint acculumator aus. Kerusakan pada accumulator menyebabkan berhentinya supply slit coil untuk diproses menjadi pipa.

\section{Waktu Kerusakan dan Waktu Perbaikan}

Data kerusakan berupa tanggal dan jam terjadi kerusakan dan perbaikan berupa waktu downtime digunakan untuk menentukan paramater distribusi waktu time to repair (TTR) dan time to failure (TTF). Perhitungan time to repair memperhitungkan jumlah waktu ketika komponen rusak hingga komponen selesai diperbaiki. Perhitungan time to failure memperhitungkan jumlah waktu ketika komponen selesai diperbaiki hingga komponen rusak kembali.

\section{Penentuan Distribusi Waktu Kerusakan dan Waktu Perbaikan}

Penentuan distribusi waktu TTR dan TTF menggunakan bantuan software minitab 16 . Distribusi yang digunakan adalah distribusi weibull dengan uji hipotesis sebagai berikut:

H0: Data time to failure dan time to repair berdistribusi weibull
H1: Data time to failure dan time to repair tidak berdistribusi weibull.

Hipotesis diterima jika P-Value $>\alpha$, dengan $\alpha=0,05$. Paramater yang digunakan pada distribusi weibull adalah Scale $(\theta)$ dan Shape $(\beta)$. fungsifungsi yang digunakan pada distribusi weibull menurut Dhilon (2002) adalah:

Fungsi keandalan

$$
R(t)=e^{-\left(\frac{t}{\theta}\right)^{\beta}}
$$

Mean time to failure (MTTF)

$$
M T T F=\theta r\left(1+\frac{1}{\beta}\right)
$$

Nilai $r\left(1+\frac{1}{\beta}\right)$ diperoleh dari $r(x)$ tabel fungsi gamma.

\section{Mean time to repair (MTTR)}

$$
\operatorname{MTTR}=\theta r\left(1+\frac{1}{\beta}\right)
$$

Nilai $r\left(1+\frac{1}{\beta}\right)$ diperoleh dari $r(x)$ tabel fungsi gamma.

Rekap hasil pengujian distribusi waktu kerusakan dan perbaikan dapat dilihat pada Tabel dibawah ini:

Tabel 1. Penentuan distribusi TTR

\begin{tabular}{|l|l|l|l|l|l|}
\hline No & Komponen & Distribusi & P-Value & Shape $(\beta)$ & Scale $(\theta)$ \\
\hline 1 & Bearing drive roll & Weibull & 0,102 & 0,980264 & 3,53194 \\
\hline 2 & Joint accumulator & Weibull & $>0,250$ & 1,40146 & 2,37087 \\
\hline 3 & Motor run out & Weibull & $>0,250$ & 1,70253 & 2,52398 \\
\hline 4 & Solenoid kickout & Weibull & $>0,250$ & 2,40831 & 1,18219 \\
\hline 5 & Bearing gergaji & Weibull & $>0,250$ & 1,49618 & 3,24853 \\
\hline 6 & Limit switch & Weibull & $>0,250$ & 3,32239 & 1,10609 \\
\hline 7 & Nepple & Weibull & 0,120 & 2,43376 & 2,03316 \\
\hline 8 & Fitting & Weibull & $>0,250$ & 2,49719 & 1,62777 \\
\hline 9 & Pulley gergaji & Weibull & $>0,250$ & 1,55386 & 2,77941 \\
\hline 10 & Shaft gergaji & Weibull & 0,146 & 1,54794 & 5,74896 \\
\hline 11 & Selang & Weibull & $>0,250$ & 2,76670 & 1,73981 \\
\hline
\end{tabular}

Tabel 2. Penentuan distribusi TTF

\begin{tabular}{|l|l|l|l|l|l|}
\hline No & Komponen & Distribusi & P-Value & Shape $(\beta)$ & Scale $(\theta)$ \\
\hline 1 & Bearing drive roll & Weibull & $>0,250$ & 1,42947 & 804,064 \\
\hline 2 & Joint accumulator & Weibull & $>0,250$ & 1,54988 & 1254,53 \\
\hline 3 & Motor run out & Weibull & $>0,250$ & 3,31116 & 1079,33 \\
\hline 4 & Solenoid kickout & Weibull & 0,072 & 1,62043 & 1576,10 \\
\hline 5 & Bearing gergaji & Weibull & $>0,250$ & 0,743537 & 784,402 \\
\hline 6 & Limit switch & Weibull & 0,219 & 5,05258 & 1231,97 \\
\hline
\end{tabular}




\begin{tabular}{|l|l|l|l|l|l|}
\hline No & Komponen & Distribusi & P-Value & Shape $(\beta)$ & Scale $(\theta)$ \\
\hline 7 & Nepple & Weibull & 0,081 & 1,49838 & 773,572 \\
\hline 8 & Fitting & Weibull & $>0,250$ & 2,23536 & 884,618 \\
\hline 9 & Pulley gergaji & Weibull & 0,215 & 1,34731 & 1474,00 \\
\hline 10 & Shaft gergaji & Weibull & $>0,250$ & 2,92925 & 1814,71 \\
\hline 11 & Selang & Weibull & $>0,250$ & 1,02160 & 858,163 \\
\hline
\end{tabular}

\section{Perhitungan MTTR dan MTTF}

Setelah diperoleh distribusi serta paramater masing-masing komponen selanjutnya dilakukan perhitungan mean time to repair (MTTR) dan mean time to failure (MTTF). Nilai MTTR dan MTTF dihitung dengan bantuan software minitab 16, sebagai berikut:

Tabel 3. Nilai MTTR

\begin{tabular}{|l|l|l|}
\hline No & Komponen & MTTR (jam) \\
\hline 1 & Bearing drive roll & 3,56259 \\
\hline 2 & Joint accumulator & 2,16051 \\
\hline 3 & Motor run out & 2,25178 \\
\hline 4 & Solenoid kickout & 1,04806 \\
\hline 5 & Bearing gergaji & 2,93350 \\
\hline 6 & Limit switch & 0,992518 \\
\hline 7 & Nepple & 1,80285 \\
\hline 8 & Fitting & 1,44422 \\
\hline 9 & Pulley gergaji & 2,49913 \\
\hline 10 & Shaft gergaji & 5,17131 \\
\hline 11 & Selang & 1,54853 \\
\hline
\end{tabular}

Tabel 4. Nilai MTTF

\begin{tabular}{|l|l|l|}
\hline No & Komponen & MTTF (jam) \\
\hline 1 & Bearing drive roll & 730,537 \\
\hline 2 & Joint accumulator & 1128,33 \\
\hline 3 & Motor run out & 968,337 \\
\hline 4 & Solenoid kickout & 1411,49 \\
\hline 5 & Bearing gergaji & 940,686 \\
\hline 6 & Limit switch & 1131,84 \\
\hline 7 & Nepple & 698,430 \\
\hline 8 & Fitting & 783,498 \\
\hline 9 & Pulley gergaji & 1352,12 \\
\hline 10 & Shaft gergaji & 1618,84 \\
\hline 11 & Selang & 850,648 \\
\hline
\end{tabular}

\section{Perhitungan Biaya Tenaga Kerja}

Biaya tenaga kerja meliputi biaya operator mesin dan biaya mekanik. Biaya-biaya yang dikeluarkan untuk operator dan mekanik dianggap sama. jumlah biaya yang dikeluarkan sesuai dengan UMK Surabaya sebesar Rp. 3.583.321,61 perbulan, sehingga menjadi Rp. 17.227,50 per jam. Operator mill 303 sebanyak 5 orang dan mekanik sebanyak 2 orang.

\section{Perhitungan Biaya Kerugian Produksi}

Biaya kerugian produksi diperoleh dari keuntungan yang hilang akibat kerusakan/perawatan mesin yang mengakibatkan mesin berhenti beroperasi. Mesin mill 303 mampu memporduksi pipa baja sebanyak 3,2 ton per jam. Harga pipa baja sebesar Rp. 13.000,00 per kg, biaya produksi pipa baja sebesar Rp. $8.500,00$ per kg. Jadi biaya kerugian perjam sebesar Rp.14.400.000,00.

\section{Perhitungan Biaya Untuk Perawatan}

Biaya untuk perawatan adalah biaya yang timbul karena adanya perawatan. Biaya untuk perawatan meliputi biaya tenaga kerja, biaya downtime (biaya downtime ditetapkan oleh perusahaan sebesar $20 \%$ dari biaya kerugian produksi) dan biaya material. Biaya perawatan dihitung dengan rumus berikut:

$\mathrm{CM}=$ (biaya tenaga kerja + biaya downtime)MTTR + biaya material

Hasil perhitungan biaya untuk perawatan dapat dilihat pada Tabel dibawah ini: 
Tabel 5. Biaya untuk Perawatan

\begin{tabular}{|c|c|c|c|c|c|c|c|}
\hline \multirow[t]{2}{*}{ No } & \multirow[t]{2}{*}{ Komponen } & \multirow{2}{*}{$\begin{array}{c}\text { Harga } \\
\text { (Rupiah) }\end{array}$} & \multirow{2}{*}{$\begin{array}{l}\text { MTTR } \\
\text { (Jam) }\end{array}$} & \multicolumn{2}{|c|}{$\begin{array}{l}\text { Biaya tenaga kerja } \\
\text { (Rupiah) }\end{array}$} & \multirow{2}{*}{$\begin{array}{c}\text { Downtime } \\
\text { (Rupiah) }\end{array}$} & \multirow[t]{2}{*}{ CM (Rupiah) } \\
\hline & & & & mekanik & operator & & \\
\hline 1 & $\begin{array}{l}\text { Bearing drive } \\
\text { roll }\end{array}$ & 930.000 & 3,56259 & 34.555 & 86.388 & 2.880 .000 & 11.621 .128 \\
\hline 2 & $\begin{array}{l}\text { Joint } \\
\text { accumulator }\end{array}$ & 1.500 .000 & 2,16051 & 34.555 & 86.388 & 2.880 .000 & 7.983.566 \\
\hline 3 & Motor run out & 10.590 .000 & 2,25178 & 34.555 & 86.388 & 2.880 .000 & 17.347 .462 \\
\hline 4 & $\begin{array}{l}\text { Solenoid } \\
\text { kickout }\end{array}$ & 2.971 .000 & 1,04806 & 34.555 & 86.388 & 2.880 .000 & 6.116 .168 \\
\hline 5 & $\begin{array}{l}\text { Bearing } \\
\text { gergaji }\end{array}$ & 888.000 & 2,9335 & 34.555 & 86.388 & 2.880 .000 & 9.691 .265 \\
\hline 6 & $\begin{array}{l}\text { Limit switch } \\
\text { carriage }\end{array}$ & 500.000 & 0,99251 & 34.555 & 86.388 & 2.880 .000 & 3.478 .489 \\
\hline 7 & Nepple & 3.887 & 1,80285 & 34.555 & 86.388 & 2.880 .000 & 5.414 .136 \\
\hline 8 & Fitting & 62.900 & 1,44422 & 34.555 & 86.388 & 2.880 .000 & 4.396 .921 \\
\hline 9 & Pulley gergaji & 950.000 & 2,49913 & 34.555 & 86.388 & 2.880 .000 & 8.449 .745 \\
\hline 10 & Shaft gergaji & 9.500 .000 & 5,17131 & 34.555 & 86.388 & 2.880 .000 & 25.018 .804 \\
\hline 11 & Selang & 64.000 & 1,54853 & 34.555 & 86.388 & 2.880 .000 & 4.711 .049 \\
\hline
\end{tabular}

\section{Biaya Perawatan Karena Kerusakan}

Biaya perbaikan akibat kerusakan komponen setiap siklus perawatan adalah biaya yang timbul akibat adanya kerusakan komponen. Biaya ini meliputi biaya kerugian produksi, biaya tenaga kerja dan biaya material. Hasil rekap perhitungan biaya perbaikan akibat kerusakan dapat dilihat pada Tabel dibawah ini:

\section{Interval Perawatan Optimal}

Interval perawatan yang optimal pada setiap komponen dihitung menggunakan paramaterparamater distribusi selang waktu kerusakan, biaya kerugian produksi akibat kerusakan dan biaya penggantian karena perawatan. Rumus perhitungan interval perawatan menurut (Taufik \& Septyani, 2015) sebagai berikut:

$$
\begin{gathered}
C f=C r+T f(C o+C w) \\
T M=\theta\left(\frac{C m}{C f(\beta-1)}\right)^{\frac{1}{\beta}}
\end{gathered}
$$

\begin{tabular}{|c|c|c|c|c|c|c|c|}
\hline \multirow[t]{2}{*}{ No } & \multirow[t]{2}{*}{ Komponen } & \multirow{2}{*}{$\begin{array}{c}\text { Harga } \\
\text { (Rupiah) }\end{array}$} & \multirow[t]{2}{*}{ MTTR (Jam) } & \multicolumn{2}{|c|}{$\begin{array}{c}\text { Biaya tenaga kerja } \\
\text { (rupiah) }\end{array}$} & \multirow{2}{*}{$\begin{array}{c}\text { Biaya } \\
\text { kerugian } \\
\text { (Rupiah) }\end{array}$} & \multirow[t]{2}{*}{ CF (Rupiah) } \\
\hline & & & & Mekanik & Operator & & \\
\hline 1 & Bearing drive roll & 930.000 & 3,56259 & 34.555 & 86.388 & 14.400 .000 & 52.662 .165 \\
\hline 2 & Joint accumulator & 1.500 .000 & 2,16051 & 34.555 & 86.388 & 14.400 .000 & 32.872 .641 \\
\hline 3 & Motor run out & 10.590 .000 & 2,25178 & 34.555 & 86.388 & 14.400 .000 & 43.287 .968 \\
\hline 4 & Solenoid kickout & 2.971 .000 & 1,04806 & 34.555 & 86.388 & 14.400 .000 & 18.189.819 \\
\hline 5 & Bearing gergaji & 888.000 & 2,9335 & 34.555 & 86.388 & 14.400 .000 & 43.485 .185 \\
\hline 6 & $\begin{array}{l}\text { Limit switch } \\
\text { carriage }\end{array}$ & 500.000 & 0,992518 & 34.555 & 86.388 & 14.400 .000 & 14.912 .297 \\
\hline 7 & Nepple & 3.887 & 1,80285 & 34.555 & 86.388 & 14.400 .000 & 26.182 .968 \\
\hline 8 & Fitting & 62.900 & 1,44422 & 34.555 & 86.388 & 14.400 .000 & 21.034 .336 \\
\hline 9 & Pulley gergaji & 950.000 & 2,49913 & 34.555 & 86.388 & 14.400 .000 & 37.239 .723 \\
\hline 10 & Shaft gergaji & 9.500 .000 & 5,17131 & 34.555 & 86.388 & 14.400 .000 & 84.592 .295 \\
\hline 11 & Selang & 64.000 & 1,54853 & 34.555 & 86.388 & 14.400 .000 & 22.550 .115 \\
\hline
\end{tabular}

Tabel 6. Biaya perawatan karena kerusakan 
Keterangan:

Cf =Biaya perbaikan karena kerusakan komponen

$\mathrm{Cr}$ =Harga komponen

Co =Biaya kerugian produksi (hourly rate)

$\mathrm{Cw}=$ Biaya tenaga kerja

$\mathrm{TM}=$ Interval perawatan
$\mathrm{CM}=$ Biaya yang dikeluarkan untuk perawatan ((biaya tenaga kerja + biaya downtime) MTTR + biaya material)

Interval perawatan yang optimal pada setiap komponen dihitung menggunakan paramaterparamater distribusi selang waktu kerusakan, biaya kerugian produksi akibat kerusakan dan biaya penggantian karena perawatan.

Tabel 7. Interval perawatan optimal

\begin{tabular}{|c|l|c|c|c|c|c|}
\hline No & \multicolumn{1}{|c|}{ Komponen } & $\begin{array}{c}\text { Shape } \\
(\beta)\end{array}$ & $\begin{array}{c}\text { Scale } \\
(\theta)\end{array}$ & CM (Rupiah) & CF (Rupiah) & TM (Jam) \\
\hline 1 & Bearing drive roll & 1,42947 & 804,064 & 11.621 .128 & 52.662 .165 & 504,649 \\
\hline 2 & Joint accumulator & 1,54988 & 1254,53 & 7.983 .566 & 32.872 .641 & 740,443 \\
\hline 3 & Motor run out & 3,31116 & 1079,33 & 17.347 .462 & 43.287 .968 & 635,824 \\
\hline 4 & Solenoid kickout & 1,62043 & 1576,1 & 6.116 .168 & 18.189 .819 & 1079,950 \\
\hline 5 & Bearing gergaji & 0,743537 & 784,402 & 9.691 .265 & 43.485 .185 & 155,163 \\
\hline 6 & $\begin{array}{l}\text { Limit switch } \\
\text { carriage }\end{array}$ & 5,05258 & 1231,97 & 3.478 .489 & 14.912 .297 & 700,170 \\
\hline 7 & Nepple & 1,49838 & 773,572 & 5.414 .136 & 26.182 .968 & 430,056 \\
\hline 8 & Fitting & 2,23536 & 884,618 & 4.396 .921 & 21.034 .336 & 399,565 \\
\hline 9 & Pulley gergaji & 1,34731 & 1474 & 8.449 .745 & 37.239 .723 & 1074,671 \\
\hline 10 & Shaft gergaji & 2,92925 & 1814,71 & 25.018 .804 & 84.592 .295 & 956,678 \\
\hline 11 & Selang & 1,0216 & 858,163 & 4.711 .049 & 22.550 .115 & 7911,301 \\
\hline
\end{tabular}

\section{PENUTUP}

Hasil penelitian menggunakan metode RCM dapat disimpulkan bahwa:

1. Analisa Preventive maintenance didapatkan interval perawatan optimal untuk 11 komponen kritis diatas sebagai berikut:

a. Interval perawatan komponen bearing drive roll accumulator yaitu 504,65 jam (21 hari).

b. Interval perawatan komponen selang yaitu 7911,3 jam (329 hari).

c. Interval perawatan komponen shaft gergaji yaitu 956,68 jam (39 hari).

d. Interval perawatan komponen bearing gergaji yaitu 155,16 jam (7 hari).

e. Interval perawatan komponen joint accumulator yaitu 740,44 jam (31 hari).

f. Interval perawatan komponen pulley gergaji yaitu1074,68 jam (45 hari).

g. Interval perawatan komponen limit switch carriage yaitu 700,17 jam (29 hari).

h. Interval perawatan komponen fitting yaitu 399,65 jam (17 hari).

i. Interval perawatan komponen nepple yaitu 430,05 jam (18 hari).

j. Interval perawatan komponen solenoid kick out yaitu 1079,95 jam (45 hari).

k. Interval perawatan komponen motor run out yaitu 635,82 jam (26 hari).

\section{DAFTAR PUSTAKA}

Aziz, M. T., \& Suprawhardana, M. S. (2010). Penerapan Metode Reliability Centered Maintenance (RCM) Berbasis Web Pada Sistem Pendingin Primer Di Reaktor Serba Guna GA. Siwabessy. JFN, 4(1).

Pranata, H. (2015). Reliability Centered Maintenance. Jakarta: Mitra Wacana media.

Sayuti, M., Muhammad, \& Rifa'i, M. S. (2013). Evaluasi Manajemen Perawatan Mesin Dengan Menggunakan Metode Reliability Centered Maintenance Pada PT.Z. Malikussaleh Industrial Engineering Journal, 2(1), 9-13.

Taufik, \& Septyani, S. (2015). Penentuan Interval Waktu Perawatan Komponen Kritis Pada Mesin Turbian DI Pt PLN (Perero) Sektor Pembangkit Ombilin. Jurnal Optimasi INdustri, 14(02), 238-258. 